\title{
Research on Case Education of Accounting and Auditing
}

\author{
Yan Zuo \\ Chongqing College of Finance and Economics, Yongchan, Chongqing, 402160
}

\begin{abstract}
Keywords: Case Education, Accounting and Auditing, Education Research
\end{abstract}
\begin{abstract}
Case teaching is based on the teaching case as the carrier, the case applied to teaching, through teacher teaching, organization of student discussion, writing case analysis report, teacher induction summary process to achieve the purpose of teaching, and then improve the theoretical level of students and practical ability of teaching methods. Case teaching reflects the purpose of quality education, which is essentially a research study, can become passive and change into a heuristic, so that students are actively involved in the state, is an effective teaching methods. Case teaching method is widely used in the practice of audit teaching. It has important practical significance to highlight the practical characteristics of teaching, to play the application function of teaching, to cultivate students' practical skills and to promote the reform and innovation of audit curriculum.
\end{abstract}

\section{Introduction}

Case education is the method of case discussion applied to classroom teaching activities. It is based on the needs of classroom teaching and teaching content, through the provision of a specific case, to guide students to participate in the analysis, discussion, expression and other activities, so that students in the specific problem situation in the positive thinking, take the initiative to explore to improve teaching and learning Quality and effectiveness, to cultivate students to understand the problem, analyze the problem and solve the problem of a comprehensive ability of a teaching method. The case is developed and developed with the development of practice and the needs of teaching. Ancient Greek philosopher, educator Socrates pioneered the first case of teaching precedent. He created the question-and-answer teaching method is actually the prototype of the case teaching. The use of case teaching in the university lectures originated in the 20th century, 20 years of Harvard University business school, from the 20th century, 40 years, Harvard University began to promote case teaching methods. By 1955, with the support of the Ford Foundation, the Harvard Business School has gradually established a relatively complete case library system from case selection, gathering, writing to all aspects of application and distribution. In the past two or three decades, case teaching in the field of rapid development of management, whether it is MBA education or undergraduate education, whether in strategic management, organization and management, or in marketing, production operations management and financial management and other management areas, You can see the fruitful results of the case. Case teaching in the domestic promotion later. In the late 1970s and early 1980s, China's theorists began to use the method of case study to study China's enterprise management issues, at the same time, the case method in the field of enterprise management teaching began to be applied. In the late 1980s and early 1990s, many colleges and universities began to apply the case method to the enterprise management teaching and scientific research work, the rise of the case teaching method, the construction of enterprise management case database and promote enterprise management case localization boom. With the deepening of curriculum reform, the extensive study of research, it will become the main role of classroom teaching in this century, more and more attention caused by the majority of teachers and students. Colleges and universities are studying and exploring the application of case teaching. Colleges and universities have developed relevant cases in different fields of specialization, studied case teaching techniques and extensively carried out exchanges with international experience. In 
2009, the China Association of Certified Public Accountants (CPA) began to introduce case teaching in the continuing education of certified public accountants and developed the first batch of cpa continuing education cases.

\section{Audit Case Teaching Problems}

The most important key factor in the successful implementation of the audit case teaching method is to select the audit case library suitable for teaching, but the audit information in real life has strong confidentiality, it is difficult to obtain the real audit information, and the audit case data suitable for teaching is more And less. Many of the teaching cases that have been used in the teaching of audit cases are mostly compiled by teachers according to the knowledge of audit theory. Such cases are separated from the real economic business and can not really mobilize the enthusiasm of students to explore. There are some colleges and universities using the teaching case is a real case, but the case is too old, with the economic environment and audit, accounting standards continue to change, has not adapted to the current economic development.

Auditing case teaching is usually taught mainly at home and abroad, the main teaching form is the teacher teaching and questioning, student answer, case discussion, etc., through the case involved in the accounting issues and audit issues analysis and discussion, to consolidate the student's audit know how. Most of the college audit teaching hours are limited, can not give students enough time to read the case, can only use the classroom time to listen to the teacher to teach, so that students understand the case is not good, it can not fully mobilize the enthusiasm of students to participate in case discussion The

At present, many colleges and universities in China audit teachers are from one school into another school, the theoretical level is relatively high, but most of the teachers basically no audit of practical experience, so the lack of perceptual knowledge, a lot of audit theory teachers themselves Can not fully understand, so more can not be easy to teach to the students, audit case teaching in order to successfully implement, not only requires teachers to have a solid theoretical knowledge, but also requires teachers to practice practical experience and knowledge, so that in case teaching In the process of better guidance to students.

\section{The Necessity and Method of Innovating Audit Case Teaching Method}

Auditing is a kind of theoretical and practical courses are strong, and the theoretical knowledge is boring, students learning initiative and enthusiasm is not high, so the theoretical knowledge is not easy to understand and absorb the students, it is difficult for students to really do the theory Guiding practice. Audit case teaching method will be realistic in the case of fresh audit into the classroom, set up a social audit business and campus teaching a bridge between. So that students can feel the real situation of audit practice, improve learning interest and motivation. The introduction of case teaching method also provides students with a real practice opportunity, students can better combine theory and practice, improve the ability to detect, analyze and solve problems, so as to achieve better teaching results. Although many colleges and universities in our country are exploring the case teaching method of auditing, but subject to many factors, such as the construction of case database, the problem of teaching method, the quality of teachers and so on. The case teaching method is only one form and does not reach the real Meaning case teaching. Therefore, the existing case teaching must be innovated.

The collection and preparation of the appropriate case database for the audit teaching is the basis for the implementation of the case teaching method. The selection of the case should be adapted to the implementation of the actual policy and can meet the teaching objectives and requirements, and stimulate the students 'imagination and fully mobilize the students' Learning initiative and initiative. Construction and enrichment of the case book for the teaching can take the following methods: audit teachers in the teaching process, according to the audit syllabus and other requirements, carefully selected to prepare appropriate teaching audit cases; many colleges and universities to implement quality courses, the school teachers The collection of the preparation of the audit case 
resources uploaded to the network platform, so that the case can be shared between the resources of the university; the other colleges and universities can also implement the school-enterprise cooperation model, colleges and universities can cooperate with the accounting firm, in the process of cooperation, From the accounting firm's daily economic business selected for the teaching of the case to be adapted, and the accounting firm can also get a senior theoretical guidance, in order to achieve the best results of win-win cooperation.

The traditional audit case teaching method mainly concentrated in the classroom time, inefficient, teaching effect is not ideal, so in the process of innovation audit case teaching method, we should make full use of all available resources. The case teaching from the classroom to the pre-class, after school, the teacher before the classroom teaching related cases through the network and other channels in advance to the students, so that students can read the case, fully understand the case, and can do pre-class thinking, Prepare for classroom case teaching. After school teachers to arrange the classroom teaching content related to the case as a post-homework, so that students can digest and absorb the classroom learning content. In addition, you can use WeChat to establish student micro-class, students can talk freely in this small group to discuss the audit related issues, teachers can use this micro-class after-school counseling, Q \& A, timely solution to students in the daily study To the various difficult problems.

The audit of the case teaching on the overall quality of teachers demanding, teachers need to have some experience in the audit and a strong comprehensive analysis of the ability to innovate the audit case teaching should attach importance to and train teachers, only to improve the quality of teachers themselves To better promote the development of audit case teaching. On the training of teachers, I think that can be carried out by the following ways: colleges and universities should encourage teachers to practice accounting firms, through such practice opportunities, teachers can accumulate more practical experience, so that the theory and practice will be better Combined with, and can collect the audit case teaching needs of the fresh case information for editing more suitable for teaching cases; colleges and universities can also employ a certain practice experience of certified public accountants in the classroom to explain some of the audit practice cycle, through To teach them a wealth of practical experience and personal experience of the audit practice, so that students can understand the real audit process in the classroom, open up students' vision, to mobilize the enthusiasm of students to learn the audit; college teachers have to actively take the initiative to improve themselves, Their knowledge of the scope and vision, always standing on the forefront of knowledge updates, so as to bring students more fresh knowledge. Schools can also take some measures to help and promote the quality of teachers to enhance their own, such as regular teaching skills of the game, lectures and so on.

In the teaching of the division of the module can save time and effort, for example, divided into: financing and investment cycle audit, sales and collection cycle audit, purchase and payment cycle audit, monetary and capital audit. This is divided into, easy to group the students to arrange audit tasks. Each group can complete the task and prevent the occurrence of plagiarism, to the students pressure and motivation. At the same time, so that each student can according to their understanding of the current task, the use of knowledge and their own understanding to solve the problem for each student to provide learning and thinking of the independent space. So that in the shortest possible time to complete the teaching objectives of the audit, then you can let the group re-exchange module, in a short time can master a lot of knowledge content.

Students should be assigned roles before the audit, such as the trial, assistant, field staff and so on. First of all to clear the division of labor, so that in practice to avoid the emergence of someone nothing to do, some people do things too much. While avoiding the audit practice in the form of real, everyone really involved, everyone contribute. Teachers throughout the training process is a secondary role, mainly to the students themselves to play to play. Teaching to try to reflect the "student-oriented, teachers, supplemented by" teaching ideas. Emphasizing the subjectivity of students, give full play to students in the learning process of initiative, enthusiasm and innovation. These are some of the methods that are more difficult to talk about in the audit teaching. How to audit the lesson is good, so that students interested in the audit of this course is a long-term project, 
both teaching design tips and teaching skills, as well as audit training on the enrichment, and audit Case teaching can provide a platform for teaching and training, but also effective convergence of teaching and training, in practice teaching is a good way.

\section{Conclusion}

Throughout the case of teaching techniques, in the application of the need to consider the teaching object, curriculum characteristics, teaching conditions and environmental requirements. The same teacher can according to their own experience, student characteristics and other factors in the teaching of different stages of dynamic adjustment. The teaching method of setting up an audit course for the accounting profession of an independent college is suitable for teaching cases, and the conditions can be discussed in the laboratory or extracurricular. Case teaching is not a simple teaching method, which involves the renewal of educational ideas, the orientation of teachers 'roles, the transformation of students' learning view and the creation of learning community. In the teaching process, teachers need to constantly improve their overall quality, enrich the knowledge, update ideas, bold innovation, to the "double teacher" development. In the teaching practice need to integrate a variety of teaching methods. To promote case teaching, not to ignore the theory of teaching, the basic concepts of the indoctrination and basic theoretical knowledge of traditional teaching is still essential, case teaching is more suitable for the cultivation of basic skills.

\section{Acknowledgements}

Fund Project: Chongqing City Board of Education reform project, 20172070

\section{References}

[1] Ha Shen Tuya. Talking about the "zero distance" induction training mode of accounting computerization specialty in higher vocational colleges [J]. Modern Economic Information. 2017 (16)

[2] Liu Mingxin. Welcome to promote the construction of accounting computerization professional construction [J] .Ba Bo Guo Leng Vocational and Technical College. 2007 (04)

[3] Hunan National Vocational College Professional Introduction Accounting computerization professional profile [J]. Journal of Hunan Vocational College of Nationalities. 2009 (04)

[4] Zhang Li, Li Zigang, Xiong Shengyin.Establishment of Effective Teaching Measures for Students' Skills Improvement in Accounting Computerization Specialty in Higher Vocational Colleges [J]. Journal of Ya'an Vocational and Technical College 2010 (04)

[5] Xu Hongtao, Chen Min.Comparison of the similarities and differences of curriculum convergence in accounting and computerization of accounting computer [J]. Science and Technology Outlook. 2017 (19)

[6] Cao Fanglin. Higher vocational colleges accounting computerization professional graduation assessment model [J] .Taiyuan City Vocational and Technical College. 2017 (06) 